\title{
Late Glacial and Holocene shore-level changes in the Aarhus Bugt area, Denmark
}

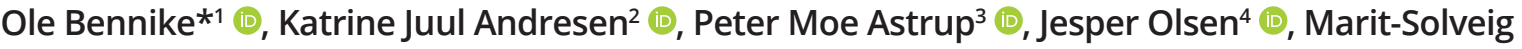 \\ Seidenkrantz ${ }^{2}$ (1)
}

${ }^{1}$ Geological Survey of Denmark and Greenland (GEUS), Aarhus, Denmark, '2Department of Geoscience and iClimate Centre, Aarhus University, Denmark, ${ }^{3}$ Moesgaard Museum, Aarhus, Denmark, ${ }^{4}$ Aarhus AMS Centre, Department of Physics and Astronomy, Aarhus University, Denmark

\begin{abstract}
We propose a new relative shore-level curve for the Aarhus Bugt area, an embayment in eastern Jylland, Denmark, based on a compilation of published and new radiocarbon ages of organic material. Lakes existed in the area during the Late Glacial and Early Holocene. Lake level rose gradually until the region was inundated by the sea at c. 9000 cal. years BP. The relative sea level reached a high stand at about 6000 cal. years BP, when the local relative sea level was c. $3 \mathrm{~m}$ above present-day mean sea level. The Aarhus Bugt area was inundated by the sea later than the Limfjord area in northern Jylland, but earlier than the Lillebælt region in southern Denmark. The shorelevel curves for these areas differ partly because the glacio-isostatic uplift was more pronounced in the Limfjord area than farther south and partly because the northern regions were inundated by the sea earlier than the southern areas.
\end{abstract}

\section{Introduction}

During the Last Glacial Maximum, large parts of Denmark were covered by the Scandinavian ice sheet (Houmark-Nielsen et al. 2012). About 21000 cal. years BP (before present, i.e. before $1950 \mathrm{CE}$ ), the ice sheet began to retreat partly because of melting and partly because of iceberg calving. As the colossal mass of glacier ice disappeared from the land areas, glacio-isostatic rebound began. Uplift of the land is still ongoing, with highest uplift rates in the northern part of Denmark and lowest in the southwestern part of the country (Vestøl et al. 2019).

Concurrent with the glacio-isostatic rebound, global mean sea level also rose as large amounts of meltwater from the retreating ice sheets flowed into the world's oceans. In total, sea level has risen about $125 \mathrm{~m}$ after the Last Glacial Maximum (Chapell \& Shackleton 1986; Lambeck et al. 2014). The combination of land uplift and sea-level rise results in local and regional relative sea-level changes. These relative sea-level changes can be reconstructed by dating samples that can be related to a former high-tide level, so-called sealevel index points. However, in the inner Danish waters, we do not have information on sea-level index points, instead we used dating of shells of marine

\author{
*Correspondence: obe@geus.dk \\ Received: 06 Apr 2021 \\ Accepted: 28 Jun 2021 \\ Published: 23 Sept 2021
}

Keywords: Aarhus Bugt, Late Glacial, shore-level changes, sea-level changes, Quaternary

\section{Abbreviations: \\ AARAMS: Aarhus AMS Centre AMS: accelerator-mass spectrometry BP: Before present \\ GEUS Bulletin is an open access, peer- reviewed journal published by the Geological Survey of Denmark and Greenland (GEUS). This article is distributed under a CC-BY 4.0 licence, permitting free redistribution, and reproduction for any purpose, even commercial, provided proper citation of the original work. Author(s) retain copyright.}

Edited by: William Colgan (GEUS)

Reviewed by: Lars Clemmensen (University of Copenhagen, Denmark), Jason Kirby (Liverpool John Moores University, UK)

Funding: See page 6

Competing interests: None declared Additional files: None provided 
gastropods or bivalves that lived below sea level, peat that accumulated in bogs above sea level or tree stumps or roots of land plants. Archaeological finds from refuse layers can also provide knowledge of sea level at a given time. These limiting data can be used to reconstruct former sea level, but sea-level curves based on such data are less well constrained than sea-level curves based on index points.

The aim of this paper is to present a shore-level curve for the Aarhus Bugt area (Fig. 1), from where we have a fairly large number of radiocarbon ages from marine, lacustrine and terrestrial deposits (Table 1). We have compiled 32 ages and propose a new curve for the Late Glacial and Holocene relative shore-level changes in the area. We use the term shore-level change rather than sea-level change because we have constructed both lake-level and sea-level changes. The shore-level curve for Aarhus Bugt fills a knowledge gap on shore-level changes in Denmark and adds to a growing number of shore-level curves from the region (e.g. Bennike \& Jensen 2011; Clemmensen et al. 2012, 2018; Bennike et al. 2012, 2019; Hede et al. 2015; Sander et al. 2016).

\section{Material and methods}

New ages used to reconstruct shore-level changes come partly from two vibrocores (502052 and 502017-1) collected in relation to mapping of sand and gravel resources and from a gravity core (AU18-MG-09G) collected during a student cruise with the Aarhus University research vessel Aurora in 2018. Core positions were selected based on shallow seismic data and sub-bottom profiles collected during the cruise. We also include new ages from sediment cores retrieved from Brabrand Sø, a lake that was formerly a fjord. In addition, ages from published literature concerning archaeological excavations on land (Andersen \& Liversage 1994; Heinemeier \& Rud 1999, 2001; Kveiborg 2014), marine archaeological investigations in Kalø Vig (Fischer \& Hansen 2005; Astrup 2018), geological studies of Aarhus Bugt (Jensen \& Bennike 2009; Rasmussen et al. 2020) and an age of a pine (Pinus sylvestris) stump that was found during deepening of the harbour at Aarhus are included (Heinemeier \& Rud 2000). The location of the dated samples appears in Fig. 1. We estimate that the elevation uncertainty is up to $\pm 0.25 \mathrm{~m}$.

The material for radiocarbon dating has been dried and submitted to a variety of laboratories; most

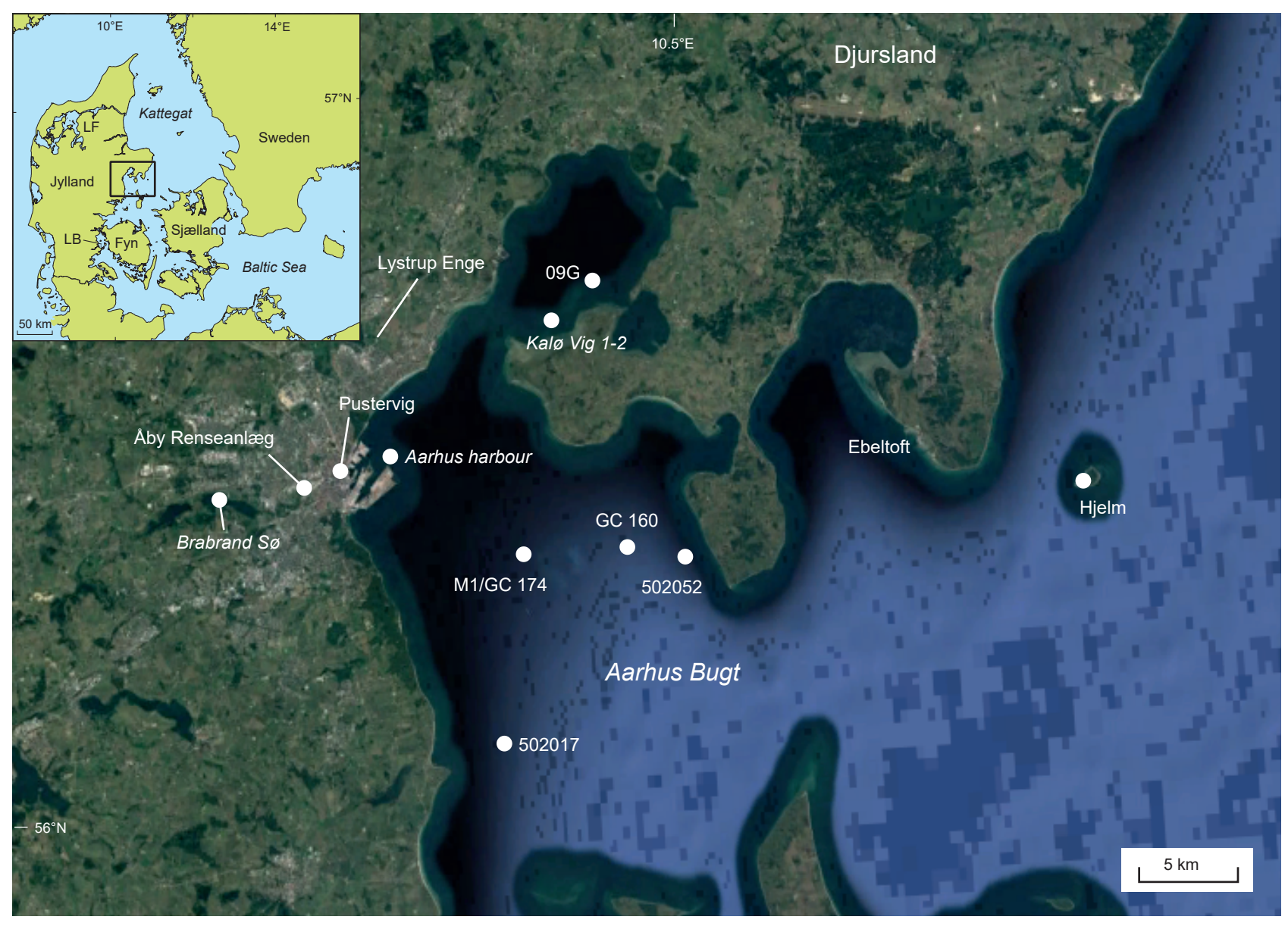

Fig. 1 Map of the Aarhus Bugt area, showing localities with radiocarbon-dated samples. LF: Limfjorden; LB: Lille Bælt (inset map). 
Table 1 Selected radiocarbon ages from the Aarhus Bugt area, Denmark.

\begin{tabular}{|c|c|c|c|c|c|c|c|c|}
\hline Core/site & Latitude $\left({ }^{\circ} \mathrm{N}\right)$ & Longitude $\left({ }^{\circ} \mathrm{E}\right)$ & $\begin{array}{l}\text { Laboratory } \\
\text { number }\end{array}$ & Material & $\begin{array}{c}\text { Elevation } \\
(\mathrm{cm})\end{array}$ & $\begin{array}{l}\text { Age } \\
\left({ }^{(4} \mathrm{C} \text { a BP }\right)^{1}\end{array}$ & $\begin{array}{l}\text { Cal. age } \\
(\text { a BP })^{2}\end{array}$ & Ref. \\
\hline $502017-1$ & 56.033 & 10.326 & Ua-57753 & Cornus sanguinea & -1120 & $7972 \pm 37$ & $8648-8993$ & $\bar{a}$ \\
\hline 502052 & 56.112 & 10.478 & AAR-29102 & Menyanthes trifoliata & -3318 & $10007 \pm 36$ & $11280-11697$ & a \\
\hline 502052 & 56.112 & 10.478 & AAR-29103 & B.nana+Dryas+S.pol. & -3420 & $10158 \pm 54$ & $11405-11971$ & a \\
\hline GC 160 & 56.117 & 10.433 & POZ-7848 & Cerastoderma edule & -2580 & $8290 \pm 40$ & $8628-9002$ & $\mathrm{~b}$ \\
\hline GC 174 & 56.117 & 10.35 & POZ-10516 & Mytilus edulis & -1640 & $7870 \pm 50$ & $8150-8477$ & b \\
\hline GC 174 & 56.117 & 10.35 & POZ-10517 & Cerastoderma lamarcki & -1740 & $8240 \pm 50$ & $8567-8976$ & $b$ \\
\hline M1 & 56.117 & 10.35 & AAR-16263 & Cerastoderma edule & -2616 & $8349 \pm 45$ & $8690-9107$ & c \\
\hline M1 & 56.117 & 10.35 & UBA-19004 & Corylus avellana & -2640 & $8565 \pm 43$ & $9473-9658$ & c \\
\hline M1 & 56.117 & 10.35 & AAR-18772 & Deciduous leaf fragment & -2660 & $8432 \pm 32$ & $9328-9530$ & c \\
\hline M1 & 56.117 & 10.35 & AAR-18773 & Betula, Meny, Schoeno & -2695 & $8910 \pm 34$ & 9906-10 183 & c \\
\hline Aarhus Havn & 56.147 & 10.24 & AAR-4859 & Pinus sylvestris stump & -1350 & $8200 \pm 70$ & $9003-9406$ & $d$ \\
\hline Pustervig & 56.158 & 10.208 & AAR-4161 & Littorina & -36 & $4885 \pm 50$ & $4943-5366$ & e \\
\hline Åby Rense. & 56.152 & 10.178 & AAR-12828 & Cerastoderma sp. & -100 & $5179 \pm 39$ & $5325-5648$ & $f$ \\
\hline Brabrand Sø & 56.146 & 10.109 & AAR-30708 & Ostrea edulis & -710 & $6260 \pm 31$ & $6495-6836$ & a \\
\hline Brabrand Sø & 56.146 & 10.109 & AAR-30707 & Ostrea edulis & -865 & $5862 \pm 34$ & $6079-6395$ & a \\
\hline Brabrand Sø & 56.146 & 10.109 & AAR-30706 & Mytilus edulis & -877 & $8512 \pm 40$ & $8967-9310$ & a \\
\hline Brabrand Sø & 56.146 & 10.109 & AAR-30705 & Twig & -890 & $9249 \pm 40$ & $10262-10560$ & a \\
\hline Brabrand Sø & 56.146 & 10.109 & AAR-30704 & Populus tremula & -898 & $9377 \pm 37$ & $10500-10702$ & a \\
\hline Brabrand Sø & 56.143 & 10.09 & AAR-30093 & Schonoplectus lacustris & -58 & $2831 \pm 32$ & $2853-3058$ & a \\
\hline Brabrand Sø & 56.143 & 10.09 & AAR-30092 & Cerastoderma & -62 & $5428 \pm 33$ & $5602-5909$ & a \\
\hline Brabrand Sø & 56.143 & 10.09 & AAR-30091 & Littorina littorea & -216 & $7274 \pm 36$ & $7564-7848$ & a \\
\hline Brabrand Sø & 56.143 & 10.09 & AAR-30090 & In situ root, woody plant & -224 & $6895 \pm 39$ & $7624-7834$ & $\mathrm{a}$ \\
\hline Kalø Vig 1 & 56.219 & 10.383 & AAR-8413 & In situ Quercus root & -670 & $7690 \pm 45$ & $8394-8586$ & g \\
\hline Kalø Vig 2 & 56.219 & 10.383 & AAR-27412 & Tree stump & -750 & $7813 \pm 75$ & $8417-8977$ & $\mathrm{~h}$ \\
\hline O9G & 56.236 & 10.418 & AAR-30088 & Twig & -1363 & $8219 \pm 46$ & 9022-9399 & a \\
\hline 09G & 56.236 & 10.418 & AAR-30089 & Twig & -1359 & $8256 \pm 41$ & $9032-9412$ & a \\
\hline Hjelm & 56.135 & 10.8 & AAR-5486 & Littorina littorea & +380 & $5525 \pm 55$ & $5674-6083$ & i \\
\hline Lystrup Enge & 56.223 & 10.225 & K-4053 & Corylus branches & -85 & $6210 \pm 105$ & $6799-7411$ & j \\
\hline Lystrup Enge & 56.223 & 10.225 & K-5730 & Populus dugout boat & -35 & $6110 \pm 100$ & $6741-7252$ & j \\
\hline Lystrup Enge & 56.223 & 10.225 & $\mathrm{~K}-6012$ & Tilia dugout boat & -81 & $6550 \pm 105$ & $7259-7614$ & j \\
\hline Lystrup Enge & 56.223 & 10.225 & $\mathrm{~K}-6335$ & Quercus tree trunk & -25 & $5450 \pm 100$ & $5950-6440$ & j \\
\hline Lystrup Enge & 56.223 & 10.225 & K-6397 & Quercus tree trunk & -48 & $6570 \pm 100$ & $7273-7613$ & j \\
\hline
\end{tabular}

${ }^{1}$ Ages in conventional radiocarbon years BP (before present = 1950; Stuiver \& Polach (1977)); ${ }^{2}$ Calibration to calendar years BP (2 sigma) is according to the INTCAL20 or MARINE20 data (Reimer et al. 2020; Heaton et al. 2020).

Ref.: References. a: this study, b: Jensen \& Bennike (2009), c: Rasmussen et al. (2020), d: Heinemeier \& Rud (2000), e: Heinemeier \& Rud (1999), f: Kveiborg (2014), g: Fischer \& Hansen (2005), h: Astrup (2018), i: Heinemeier \& Rud (2001), j: Andersen \& Liversage (1994).

samples, however, have been dated at the Aarhus AMS Centre (AARAMS; marked AAR in Table 1). These are partly remains of land plants and shells from marine molluscs. Most of the age determinations were performed by accelerator-mass spectrometry (AMS) by measuring the ratio of ${ }^{14} \mathrm{C}$ to ${ }^{12} \mathrm{C}$ atoms (Olsen et al. 2009), but ages marked $\mathrm{K}$ in Table 1 are conventional ${ }^{14} \mathrm{C}$ ages. The ages are stated in conventional radiocarbon years BP and corrected for isotope fractionation by normalising to a $\delta^{13} \mathrm{C}$ value of $-25 \%$ VPDB (Stuiver \& Polach 1977). The radiocarbon ages are calibrated to calendar years before now using the CALIB version 8.2 program (Stuiver et al. 2021). For marine samples, we used the marine calibration curve MARINE20, and for terrestrial samples, we used the INTCAL20 curve. For marine samples, we used a reservoir age of 400 years (i.e. $\Delta R=-150$ years). Both the new ages and previously published ages have been (re)calibrated for this study.

\section{Sediments and macrofossils}

The sediments in the cores from Aarhus Bugt area encompass till deposits from the last glaciation (Weichselian), Late Glacial lacustrine clay, Holocene non-marine deposits and, finally, Holocene marine sediments. Late Glacial fossiliferous (terrestrial and lacustrine plants and invertebrates) deposits were found in vibrocore 502052, which was $11.6 \mathrm{~m}$ long and collected at a water depth of $29.1 \mathrm{~m}$ (Fig. 1 and Table 1). The Late Glacial flora comprised the woody plants Betula nana, Dryas octopetala, Salix polaris and Empetrum nigrum. Macrolimnophytes were represented by Menyanthes trifoliata, Potamogeton filiformis, P. perfoliatus, P. natans, Callitriche hermaphroditica and Chara sp. Invertebrates comprised the leach Erpobdella sp., the ostracods Cytherissa lacustris, Limnocythere sp., Candona sp., the gastropods Valvata cristata and $V$. piscinalis, the bivalve Pisidium sp. and the bryozoan Cristatella mucedo. 
A subsample of Betula nana, Dryas octopetala and Salix polaris remains was dated to the Younger Dryas, a cold period at the end of the Weichselian (Table 1). This is in accordance with the flora and fauna, which are typical of Younger Dryas deposits in the region (Bennike et al. 2004). The terrestrial plants indicate a tree-less, tundra-like landscape characterised by dwarf shrub heaths. The Early Holocene terrestrial flora from Aarhus Bugt included the trees Betula sect. Albae (tree birch), Populus tremula (aspen), Pinus sylvestris (pine) and Alnus glutinosa (alder), indicating a landscape with open forests.

Vibrocore 502017-1 shows an example of a succession with clayey till, peat, lacustrine gyttja, marine mud and, finally, marine sand and gravel (Fig. 2). The lower part of the peat is dominated by stems and leaves of the brown moss Scorpidium, whereas the upper part of the peat is dominated by twigs, indicating that the former bog was overgrown by trees or bushes. Woody plants are represented by Alnus glutinosa, Betula sect. Albae and Cornus sanguinea. A fruit stone of the latter, which came from the upper part of the peat, was dated to c. 8850 cal. years BP (Fig. 2). The lacustrine gyttja is dominated by vegetative remains of Phragmites; it also contains numerous shells of lacustrine cladocerans. The

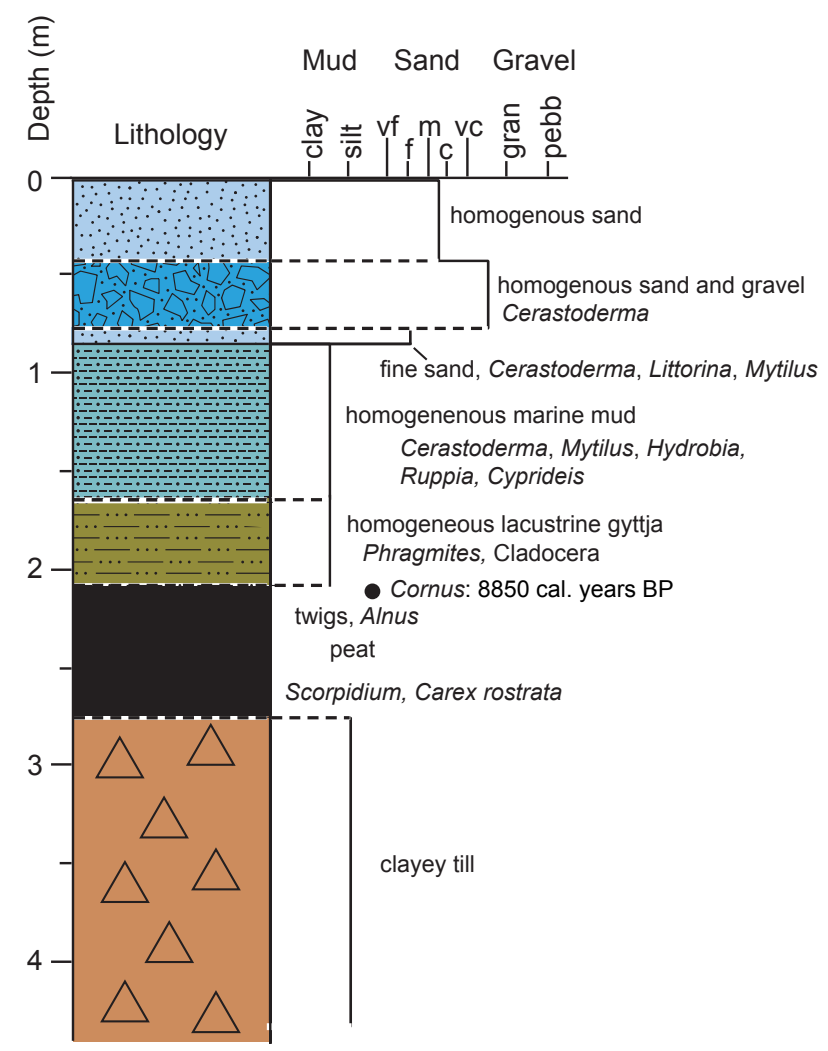

Fig. 2 Sedimentological log of vibrocore 502017-1, collected at $56.033^{\circ} \mathrm{N}, 10.326^{\circ} \mathrm{E}$, at a water depth of $9.1 \mathrm{~m}$. The presence of peat with remains of Alnus overlain by lacustrine gyttja and marine mud shows that the area has been transgressed by the sea. A fruit stone of Cornus sanguinea was dated to c. 8850 cal. years BP (Table 1). marine mud contains a mollusc fauna that indicate lowered salinity and the ostracod Cyprideis torosa, which is typical of environments with low and strongly fluctuating salinities (Frenzel et al. 2012; Pint et al. 2012). The submerged macrolimnophyte Ruppia indicates shallow water. The marine mud is overlain by marine sand and gravel, presumably reflecting an increasing energy level as the sea level rose.

\section{Shore-level changes}

In Fig. 3, we have plotted ages against elevation for marine, lacustrine and terrestrial deposits. Based on these ages, we suggest a curve that shows the development of the shore level in the Aarhus Bugt region over the last 12000 years. The dated material comes from different sources, and it is difficult to quantify the vertical error on the samples, but we suggest an error of $\pm 0.5 \mathrm{~m}$. Peat can be compacted significantly when covered by sand and many metres of seawater, which will lower the deposit (Baeteman et al. 2012).

The curve is, thus, not well constrained, and we only indicate a likely development with a dashed line. The oldest age based on remains of dwarf shrubs from vibrocore 502052 yielded an age of 11 405-11 971 cal. years BP (Table 1). The lithology and fossil content of the core shows that at this time, there were lakes in the deep parts of Aarhus Bugt. The water level in the lakes rose in the following period, and the lakes became larger. In the Early Holocene, peat bogs were probably widespread in wet areas of the Aarhus Bugt area, whereas more dry areas were forested.

Based on the radiocarbon ages, it appears that the sea began to inundate the Aarhus Bugt area about 9000 years ago (Fig. 3), as also concluded by Rasmussen et al. (2020). The marine inundation occurred because the rising global sea level surpassed the local glacio-isostatic land uplift of the area. At c. 9000 cal. years BP, global mean sea level was approximately $15 \mathrm{~m}$ lower than today (Lambeck et al. 2014). Initially, mixing of freshwater and seawater in the littoral zone created brackish conditions, as evidenced by the occurrence of low salinity species associated with shallow-water conditions, such as the bivalves Cerastoderma sp. and Mytilus edulis, the gastropods Littorina littorea and Hydrobia sp. and the ostracod Cyprideis torosa. The relative sea-level rose until about 6000 cal. years ago, when it reached its maximum (Fig. 3). The timing of the sea-level maximum is constrained by dating of a shell of Littorina from a raised beach ridge on the island of Hjelm. The marine limit on the island is c. 3 $\mathrm{m}$ above mean sea level, but raised beaches occur up to $5.3 \mathrm{~m}$ (Mertz 1924). The shell was found at an elevation of $3.8 \mathrm{~m}$, and the beach was probably deposited during a storm. The shell yielded an age of c. 5900 cal. years BP (Table 1; Heinemeier \& Rud 2001). At Aarhus, the marine 


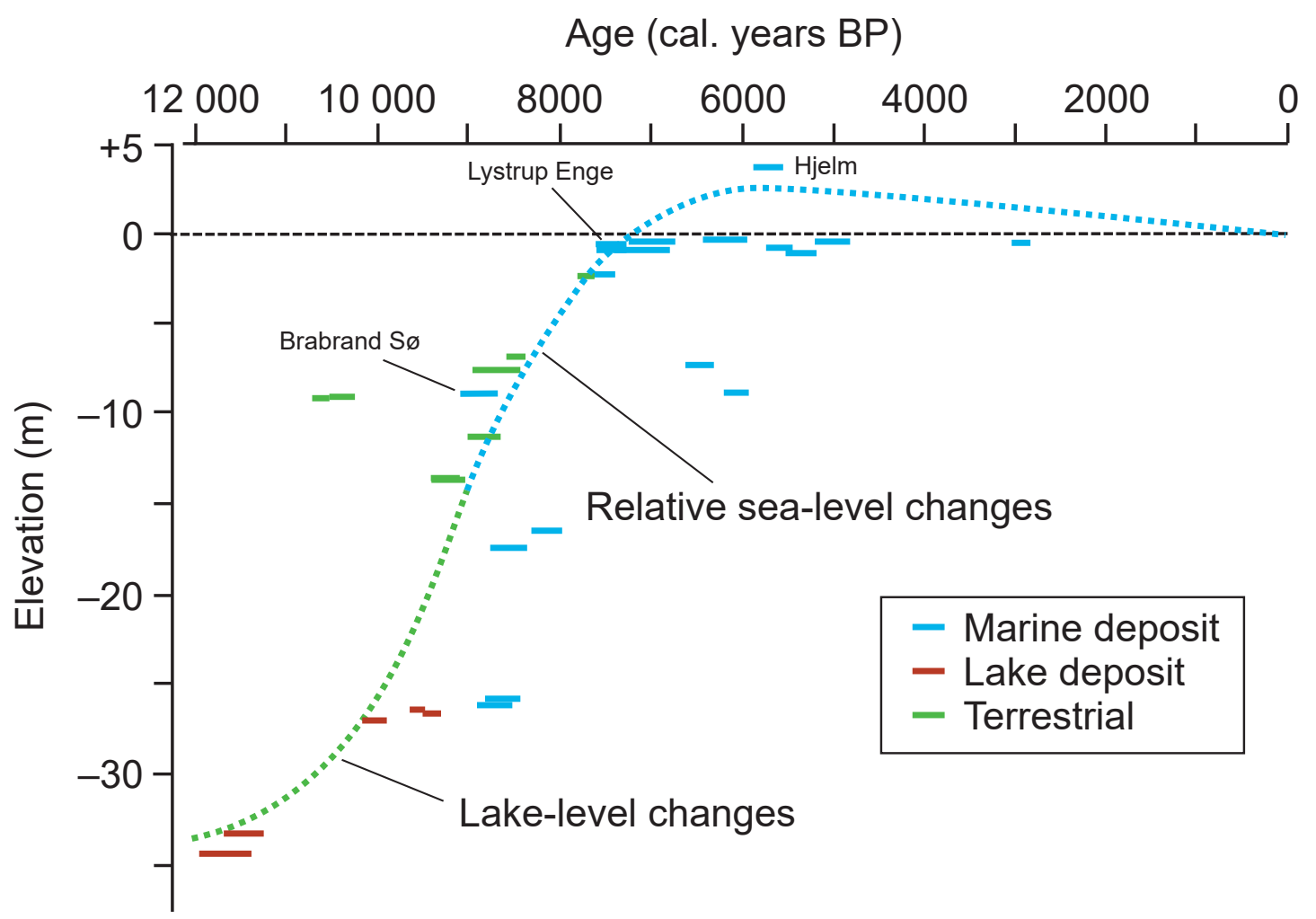

Fig. 3 Radiocarbon ages from the Aarhus Bugt area, plotted against elevation. The length of the bars represents the uncertainty range in the calibrated age (Table 1). The dashed curve shows our best estimate of the relative shore-level changes from c. 12000 cal. years BP until today, with the shift from green to blue colour, indicating the time of the marine inundation of the Aarhus Bugt area.

limit is c. $2.5 \mathrm{~m}$, at Ebeltoft, it is c. $3.5 \mathrm{~m}$ and in the northeastern part of Djursland, it is c. $5 \mathrm{~m}$ above present levels (Mertz 1924). Over the last 6000 years, global sea levels have been largely stable (e.g. Lambeck et al. 2014), whilst in the Aarhus Bugt area, this period is marked by land uplift out-pacing the rate of sea-level rise resulting in a fall in the relative sea level. We have indicated a steady decline until today, but this part of the curve is poorly constrained with data and very uncertain (Fig. 3).

Dating of a Mytilus edulis (blue mussel) shell from marine deposits in lake Brabrand Sø gave a surprisingly old age (Fig. 3). This indicates that the reservoir age was more than 400 years in the early stages of the fjord. It is also seen that two ages from Lystrup Enge appear to be too old. These ages come from samples deposited in shallow water close to the former seashore.

Comparisons with other shore-level curves from Denmark (Bennike \& Jensen 2011; Bennike et al. 2019) show similar trends to the curve from the Aarhus Bugt area (Fig. 4). However, marine waters inundated the western Limfjord earlier than Aarhus Bugt, which, in turn, was inundated earlier than southern Lillebælt. Raised marine deposits are found up to $5 \mathrm{~m}$ above present sea level in the western Limfjord area, whereas raised marine deposits are not found in southern Lillebælt, where the rate of sea-level rise surpassed the glacio-isostatic uplift.

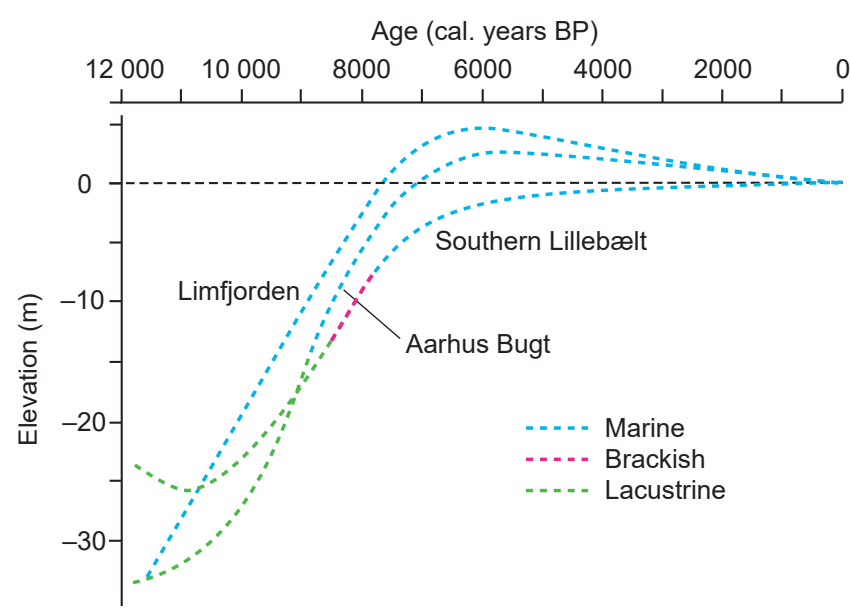

Fig. 4 Comparison of shore-level curves for the western Limfjord area (Bennike et al. 2019), the Aarhus Bugt (this study) area and southern Lillebælt region (Bennike \& Jensen 2011).

\section{Conclusions}

During the Younger Dryas, most of Aarhus Bugt was dry land with dwarf shrub heaths, but small lakes existed locally. In the earliest Holocene, most of Aarhus Bugt was dry land, but lakes soon filled the deeper parts of the area. The lakes expanded in size and shore-level rose. During this period, the trees Betula sect. Albae, Populus tremula, Pinus sylvestris and Alnus glutinosa immigrated to 
the region forming open forests. Rising global sea levels resulted in a marine inundation of the deepest parts of Aarhus Bugt at about 9000 cal. years BP, and the relative sea level rose gradually during the following millennia and reached a high stand at c. 6000 cal. years BP, as documented by raised beach ridges on Hjelm island. We propose that the relative sea level fell gradually during the Late Holocene due to gradual glacio-isostatic rebound, but the timing is not yet fully constrained.

\section{Acknowledgements}

We thank the captain (Torben Vang) and crew of R/V Aurora for excellent help during the marine cruise and also thank the students on the course for their diligent work. Uffe Rasmussen and Hans Skov from Moesgaard Museum are thanked for information on samples from Hjelm, Aaby Renseanlæg and Pustervig in Aarhus. The shore-level curve was constructed as part of the project 'Kystzonens geodynamik i Nationalpark Mols Bjerge' (Geocenter Danmark 2021). We also thank the project group, Bent Odgaard and Jens Reddersen, for good discussions. Journal referees Lars B. Clemmensen and Jason Kirby provided constructive comments to the manuscript.

\section{Funding statement}

This study was supported by Geocenter Denmark and National Park Mols Bjerge. We also acknowledge funding through the Danish Council for Independent Research (grant nos. 7014-00113B (G-Ice) and 0135-00165B (GreenShelf) to MSS), and the project has also received funding from the European Union's Horizon 2020 research and innovation program under Grant Agreement No. 869383 (ECOTIP; MSS).

\section{Author contributions}

OB: macrofossil analyses and manuscript writing. JO: radiocarbon dating. KJA, PMA and MSS: field work and editing of the manuscript.

\section{References}

Andersen, S.H. \& Liversage, D. 1994: Ertebøllebåde fra Lystrup. Kuml 39, 7-38. (In Danish)

Astrup, P.M. 2018: Sea-level change in Mesolithic southern Scandinavia. Aarhus: Jutland Archaeological Society, 207 pp.

Baeteman, C., Waller, M. \& Kiden, P. 2011: Reconstructing middle to late Holocene sea-level change: A methodological review with particular reference to 'A new Holocene sea-level curve for the southern North Sea' presented by K.-E. Behre. Boreas 40, 557-572. https://doi. org/10.1111/j.1502-3885.2011.00207.x

Bennike, O. \& Jensen, J.B. 2011: Postglacial relative shore level changes in Lillebælt, Denmark. Geological Survey of Denmark and Greenland Bulletin 23, 37-40. https://doi.org/10.34194/geusb.v23.4834

Bennike, O., Jensen, J.B., Lemke, W., Kuijpers, A. \& Lomholt, S. 2004: Lateand postglacial history of the Great Belt, Denmark. Boreas 33(1), 18-33. https://doi.org/10.1080/03009480310006952

Bennike, O., Andreasen, M.S., Jensen, J.B. \& Noe-Nyegaard, N. 2012: Early Holocene sea-level changes in Øresund, Scandinavia. Geological Survey of Denmark and Greenland Bulletin 26, 29-32. https://doi.org/10.34194/ geusb.v26.4744

Bennike, O., Nørgaard-Pedersen, N., Jensen, J.B., Andresen, K.J. \& Seidenkrantz, M.-S. 2019: Development of the western Limfjord, Denmark after the last deglaciation: a review with new data. Bulletin of the Geological Society of Denmark 67, 53-73. https://doi.org/10.37570/ bgsd-2019-67-04

Chapell, I. \& Shackleton, N.I. 1986: Oxygen isotopes and sea level. Nature 324, 137-140. https://doi.org/10.1038/324137a0

Clemmensen, L.B., Murray, A.S. \& Nielsen, L. 2012: Quantitative constraints on the sea-level fall that terminated the Littorina Sea Stage, southern Scandinavia. Quaternary Science Reviews 40, 54-63. https:// doi.org/10.1016/j.quascirev.2012.03.001

Clemmensen, L.B., Hougaard, I.W., Murray, A.S., Pedersen, S.S. 2018: A high-resolution sea-level proxy dated using quartz OSL from the Holocene Skagen Odde spit system, Denmark. Boreas 47(4), 1184-1198. https://doi.org/10.1111/bor.12319

Fischer, A. \& Hansen, J.S. 2005: Mennesket og havet i ældre stenalder. In: Bunte, E. (ed.): Arkeologi och naturvetenskap, 277-297. Lund: Gyllenstiernska Krapperupstiftelsen. (In Danish)

Frenzel, P., Schulze, I. \& Pint, A. 2012: Noding of Cyprideis torosa valves (Ostracoda) - a proxy for salinity? New data from field observations and a long-term microcosm experiment. International Review of Hydrobiology 97, 314-329. https://doi.org/10.1002/iroh.201211494

Geocenter Danmark. 2021: Kystzonens geodynamik i Nationalpark Mols Bjerge. Naturrapporter fra Nationalpark Mols Bjerge, 32, 84 pp. https:// nationalparkmolsbjerge.dk/media/290596/npmb-naturrapport-nr-32-kystzonens_geodynamik_slut-08032021-komp.pdf (accessed June 2021)

Heaton, T.J. et al. 2020: Marine20 - the marine radiocarbon age calibration curve (0-55,000 cal BP). Radiocarbon 62, 779-820. https://doi. org/10.1017/rdc.2020.68

Hede, M.U., Sander, L., Clemmensen, L.B., Kroon, A., Pejrup, M. \& Nielsen, L. 2015: Changes in Holocene relative sea-level and coastal morphology: A study of a raised beach ridge system on Samsø, southwest Scandinavia. The Holocene 25(9), 1402-1414. https://doi. org/10.1177/0959683615585834

Heinemeier, J. \& Rud, N. 1999: Danske arkæologiske AMS 14C-dateringer, Aarhus 1998. Arkæologiske udgravninger i Danmark 1998, 327-345. Copenhagen: Det Arkæologiske Nævn.

Heinemeier, J. \& Rud, N. 2000: AMS 14C-dateringer, Aarhus 1999. Arkæologiske udgravninger i Danmark 2000, 296-313. Copenhagen: Det Arkæologiske Nævn.

Heinemeier, J. \& Rud, N. 2001: AMS 14C-dateringer, Aarhus 2000. Arkæologiske udgravninger i Danmark 2001, 313-328. Copenhagen: Det Arkæologiske Nævn.

Houmark-Nielsen, M., Linge, H., Fabel, D., Schnabel, C., Xue, S., Wilcken, K.M. \& Binnie, S. 2012: Cosmogenic surface exposure dating the last deglaciation in Denmark: discrepancies with independent age constraints suggest delayed periglacial landform stabilisation. Quaternary Geochronology 13,1-17. https://doi.org/10.1016/j.quageo.2012.08.006

Jensen, J.B. \& Bennike, O. 2009: Geological setting as background for methane distribution in Holocene mud deposits, Århus Bay, Denmark. Continental Shelf Research 29(5-6), 775-784. https://doi. org/10.1016/j.csr.2008.08.007

Kveiborg, J. 2014: FHM 4880 Åby Renseanlæg-Regnvandsbassin Åby sogn, Hasle herred, Århus amt. Stednr. 15.03.10. KUAS-journal nummer: 20087.24.02/FHM-006. Report for Moesgaard Museum, 156 pp. (In Danish)

Lambeck, K., Rouby, H., Purcell, A., Sun, Y. \& Sambridge, M. 2014: Sea level and global ice volumes from the Last Glacial Maximum to the Holocene. Proceedings of the National Academy of Sciences of the United States of America 111(43), 15296-15303. https://doi.org/10.1073/pnas.1411762111

Mertz, E.L. 1924: Oversigt over de sen- og postglaciale Niveauforandringer i Danmark. Danmarks Geologiske Undersøgelse II. Række 41, 49 pp. https://doi.org/10.34194/raekke2.v41.6827 (In Danish)

Olsen, J., Rasmussen, P. \& Heinemeier, J. 2009: Holocene temporal and spatial variation in the radiocarbon reservoir age of three Danish fjords. Boreas 38, 458-470. https://doi.org/10.1111/j.1502-3885.2009.00088.x

Pint, A., Frenzel, P., Fuhrmann, R., Scharf, B. \& Wennrich, V. 2012: Distribution of Cyprideis torosa (Ostracoda) in Quaternary athalassic sediments in Germany and its application for palaeoecological reconstructions. International Review of Hydrobiology 97(4), 330-355. https://doi.org/10.1002/iroh.201111495

Rasmussen, P., Pantopoulos, G., Jensen, J.B., Olsen, J., Røy, H. \& Bennike, O. 2020: Holocene sedimentary and environmental development of Aarhus Bay, Denmark - a multi-proxy study. Boreas 49(1), 108-128. https://doi.org/10.1111/bor.12408

Reimer, P. et al. 2020: The IntCal20 Northern Hemisphere radiocarbon age calibration curve (0-55 cal kB). Radiocarbon 62, 725-757. https:// doi.org/10.1017/RDC.2020.41

Sander, L., Hede, M.U., Fruergaard, M., Nielsen, L., Clemmensen, L.B., Kroon, A., Johannessen, P.N., Nielsen, L.H. \& Pejrup, M. 2016: Coastal 
lagoons and beach ridges as complementary sedimentary archives for the reconstruction of Holocene relative sea-level changes. Terra Nova 28(1), 43-49. https://doi.org/10.1111/ter.12187

Stuiver, M. \& Polach, H.A. 1977: Discussion of reporting 14C data. Radio carbon 19(3), 355-363. https://doi.org/10.1017/s0033822200003672
Stuiver, M., Reimer, P.J. \& Reimer, R.W. 2021: CALIB 8.2 [WWW program]. http://calib.org (accessed June 2021)

Vestøl, O., Ågren, J., Steffen, H., Kierulf, H. \& Tarasov, L. 2019: NKG2016LU: a new land uplift model for Fennoscandia and the Baltic Region. Journal of Geodesy 93, 1759-1779. https://doi.org/10.1007/s00190-019-01280-8 